\title{
Review Paper \\ Life Expectancy in Rural Areas of Kurdistan Province, Iran in 2013
}

\author{
Rahmatolah Bahrami $^{*}$ (), Kamran Noori ${ }^{1}$ (]) \\ 1. Department of Geography and Rural Planning, Faculty of Social Sciences, Payame Noor University, Tehran, Iran.
}

\begin{tabular}{|c|c|}
\hline 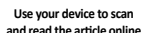 & \\
\hline & Citation Bahrami R, Noori K. Life Expectancy in Rural Areas of Kurdistan Province, Iran in 2013. Journal of Advances in \\
\hline 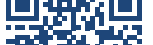 & Environmental Health Research. 2021; 9(3):177-182. http://dx.doi.org/10.32598/JAEHR.9.3.1180 \\
\hline 䓢 & doij $j^{\circ}$ http://dx.doi.org/10.32598/JAEHR.9.3.1180 \\
\hline
\end{tabular}

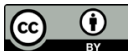

Article info:

Received: 18 Feb 2020

Accepted: 12 May 2020

Publish: 01 Jul 2021

\section{Keywords:}

Mortality, Life expectancy, Human development, Kurdistan, Rural

\begin{abstract}
Life expectancy at birth is one of the most important indicators of the social, economic, cultural, and health development in any society. This descriptive epidemiological study aims to measure life expectancy by age and gender in rural areas of Kurdistan Province, Iran. Data were collected directly using mortality information obtained from the health center of Kurdistan Province and the registered population in 2013. The findings showed that life expectancy is different in rural areas of Kurdistan Province. Life expectancy at birth in rural areas of the Province was estimated at 70.6 years on average, where it was 72 years for women and 69.3 years for men. The highest life expectancy of men is in Saqez city with 70.6 and the lowest in Kamyaran and Devandarah city with 68.6 years. The highest life expectancy is estimated in rural women with 74 years in Baneh city and the lowest in Dehgolan city with 69.9 years, respectively. The results showed different years of life expectancy in terms of gender in rural areas of Kurdistan Province. The national average life expectancy is about 2 years higher than that in rural areas of Kurdistan Province. Therefore, it is necessary to improve the life expectancy in these Province via fair distribution of facilities and services and prioritizing its rural areas in health planning.
\end{abstract}

\section{Introduction}

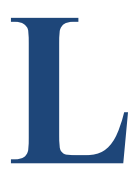

ife expectancy at birth is one of the three indicators of human development that have been used since 1991 along with the ratio of literacy and gross national product by the United Nations Development Program to determine the degree of development in the countries [1]. Life expectancy is one of the indicators of hope to life, which measures the fatal consequences of diseases and injuries. It summarizes life expectancy at birth in a life table for each age and gender group, and is the most useful indicator that shows the overall mortality level of a population by number [2]. Life expectancy at birth represents the average number of years a newborn is expected to live, if current mortality rates continue to apply. It can be estimated by age and gender [3], and is affected by factors such as income, education, health, and nutrition [4]. It is estimated to be 83-86 years in developed countries [5]. On a global scale, women's life

\footnotetext{
* Corresponding Author:

Rahmatolah Bahrami, PhD.

Address: Department of Geography and Rural Planning, Faculty of Social Sciences, Payame Noor University, Tehran, Iran

Phone: +98 (918) 8732944

E-mail: rahmat.bahrami1342@gmail.com
} 
expectancy is usually higher than men's. The difference in life expectancy between men and women in developing countries, where the number of people under the age of 15 is more than forty percent of the total population. The main reasons are the high number of births given by women and their death during giving birth [6].

One of the main features in preparing a life table is the population changes considering the impact of mortality in a community [7]. Another feature is the quantitative evolution of the population based on a certain pattern of mortality for the future [8]. The life table for determining life expectancy is used in different ways. Experts in demography, health and statistics use the life table to estimate the rates of survival, fertility, migration, widowhood, marriage, population growth, or future population [9]. Measuring the level of health and performance of the health care providers using a systematic approach allows comparison between different types which is one of the main challenges is the health system [3].

Kurdistan Province is one of the underdeveloped Provinces of Iran in the field of human development, ranked $26^{\text {th }}[10]$. The rural population of Kurdistan Province in 2016 made up $26 \%$ of its total population [11]. There is a necessity for addressing the issue of life expectancy in this Province considering the fact that the basis for achieving development in any society is its human development. Estimation of life expectancy in rural areas can show their level of health facilities and services as well as economic well-being of Kurdistan Province. Therefore, this study aims to investigate life expectancy in rural communities of Kurdistan Province. The result of such studies can be a guide for policymakers in the health sector to allocate funds fairly and find out which resources, facilities and services are required.

\section{Materials and Methods}

This is a descriptive-analytical study. The study population was data from rural areas of 10 towns of Kurdistan Province in 2013 [12]. The main study variables were mortality rate, birth rate, age, sex and place of residence. The mortality rate by age and gender was obtained according to data prepared from Kurdistan University of Medical Sciences. By using these data, mortality rate (nmx), and the probability of dying (nqx) for each age group were calculated according to the following Equations (1-6):

$E(i)=T(i) / L(i)$ : Life expectancy for people in the i age group

i: age group ai: Correction factor for calculating years of life in age group $\mathrm{i}$.

pi: The first population of the year in the age group $i$.

di: Number of deaths in the age range $i$.

ni: Years related to the age group $i$.

Mi: Probability of death at age i, As long as those people are alive before they die.

$\mathrm{Px}=$ Probability of population survival

$\mathrm{Qx}=$ Probability of population mortality

$\mathrm{qxi}=\mathrm{mxi} /[1+(1-\mathrm{axi}) \mathrm{mxi}]$

I (i): Hypothetical population of death in the hypothetical population of $i$.

L (i): Years of life between the ages group i.

T(i): Cumulative years of life, Addition of column 1 (i) $\mathrm{s}$, From the bottom to the row of group

1) $q_{i}=\frac{n_{i} M_{i}}{1+n_{i}\left(1-a_{i}\right) M_{i}}, M_{i}=\frac{D_{i}}{P_{i}}$

Probability of death in age $\mathrm{i}$

2) $l_{i+1}=l_{i}\left(1-q_{i}\right)$

Number of live population at the beginging of the year: 10000

3) $l_{i}=n_{i}\left(l_{i+1}+a_{i}\left(l_{i}-l_{i+1}\right)\right)$

The Number of year that a person live at a distance of $i$

4) $w, L_{w}=\frac{l_{w}}{M_{w}}$

The latest age group above 75

5) $T_{a}=\sum_{i=a}^{w} L i$

Total number of people, the yaers that living people livie at the begining of each i-a interval

6) $e_{a}=\frac{T_{a}}{l_{a}}$

Life expectancy for a certain age

$1 \mathrm{xi}+1=(1-\mathrm{qxi}) \times 1 \mathrm{xi}$

GIS software was used to plot the level of life expectancy among men and women. Then, to determine the level of Kurdistan Province in the health system of Iran compared to the average level of the whole country, following variables were used: ratio of active hospitals to the population, ratio of hospital beds to the popula- 
tion, ratio of the number of active beds to the number of heart patients, ratio of the number of health centers to the population, the number of clinics, pharmacies, nursing homes, rehabilitation centers, laboratories, safe drinking water facilities, rural income and etc., all of which were prepared from the Statistics Center of Iran.

\section{Results and Discussion}

Based on the results of surveys conducted in rural areas of 10 towns of Kurdistan Province, life expectancy at birth in years for men and women in these areas in 2013 and their comparison are presented in Tables 1, 2 and 3 , based on the probability of dying for different age groups. The highest life expectancy at birth for men and women in rural areas of the Province was 70.6 it is 72 years for women and 69.3 years for men. The highest life expectancy at birth for men was in Saqqez (70.9 years) while the lowest level was in Bijar (67.9 years). The highest life expectancy at birth for women was in Baneh (74 years) and the lowest level was in Divandareh (69.4 years). Overall, the results showed that the level of life expectancy at birth in rural areas of Kurdistan Province was lower compared to the national level. Based on the findings, the highest average of life expectancy at birth was 70.6 years; in Saqqez it was 72.2 years, Baneh 71.9 years, Sanandaj 71.5 years, Sarvabad 71.71 years, Qor- veh 70.6 years, Kamyaran 70.3 years, Bijar 69.5 years and Divandareh is 69 years (Tables 1, 2 and 3).

According to a survey by the Statistics Center of Iran in 2016, the average life expectancy at birth in rural areas of Kurdistan Province was 70.60 years compared to rural areas of the whole country which was 73.21 years. As illustrated in Figures 1, 2 and 3 based on gender, the average life expectancy at birth in rural areas of the whole country for men was 71.71 years, while in Kurdistan Province it was 69.40 years; for women, it was 74.71 years in the whole country and 72 years in Kurdistan Province. Life expectancy level in some rural areas of towns such as Baneh (74 years) was almost equal to the level of the whole country. Women in rural areas of Sanandaj had the lowest life expectancy (70.6 years). For men, the highest and lowest years of life expectancy were in Saqqez (70.9 years) and Kamyaran (68.10 years), respectively.

In a comparative study in 2016, the average life expectancy in rural areas of Kurdistan province with rural areas showed the whole country, average of Rural areas in Iran is 73.21 , and average of Rural areas in Kurdistan province is 70.60 , the average life expectancy in rural areas of whole country for men is 71.71 but for Rural areas in Kurdistan province is 69.4 and also average life expectancy for women in rural areas of whole country is 74.71 and for Kurdistan

Table 1. Life expectancy at birth (y) for males in ten towns of Kurdistan Province, 2013

\begin{tabular}{|c|c|c|c|c|c|c|c|c|c|c|c|}
\hline $\begin{array}{c}\text { Age } \\
\text { Groups }\end{array}$ & Sanandaj & Saqqez & Marivan & Baneh & Qorveh & Kamyaran & Bijar & Dehgolan & Divandareh & Sarvabad & $\begin{array}{c}\text { Age } \\
\text { Median }\end{array}$ \\
\hline-1 & 70.6 & 70.9 & 69.9 & 69.9 & 68.8 & 68.6 & 68.9 & 68.7 & 68.6 & 69.6 & 69.4 \\
\hline $1-4$ & 69.8 & 70 & 68.5 & 69.8 & 67.7 & 67.8 & 67.2 & 67.8 & 67.8 & 69.8 & 68.5 \\
\hline $5-9$ & 67.8 & 67.3 & 4.66 & 66.7 & 65.8 & 65.9 & 66.3 & 65.4 & 65.4 & 67.7 & 66.5 \\
\hline $10-14$ & 63.1 & 62.8 & 5.61 & 62 & 90.9 & 60.9 & 61.3 & 60.5 & 60.5 & 63.3 & 61.8 \\
\hline 15-19 & 58.2 & 57.9 & 66.7 & 57.1 & 56 & 56 & 56.6 & 55.6 & 55.6 & 58.4 & 56.9 \\
\hline $20-24$ & 53.3 & 53.2 & 51.9 & 52.3 & 51.3 & 51.4 & 51.7 & 50.9 & 50.8 & 53.9 & 52.2 \\
\hline $25-29$ & 48.5 & 48.3 & 47.3 & 47.9 & 46.9 & 46.8 & 46.9 & 46.1 & 45.9 & 49.4 & 5.47 \\
\hline $30-34$ & 43.8 & 43.6 & 42.5 & 43.2 & 42.2 & 42.3 & 42.3 & 42.5 & 41.5 & 44.6 & 42.8 \\
\hline $35-39$ & 39.3 & 39.9 & 38 & 38.5 & 37.5 & 38.1 & 37.6 & 36.2 & 36.8 & 39.7 & 38.2 \\
\hline $40-44$ & 34.7 & 34 & 32.1 & 33.6 & 33.1 & 5.33 & 33.1 & 32.3 & 32.1 & 35 & 33.4 \\
\hline $45-49$ & 30 & 29.4 & 29.2 & 28.8 & 29.1 & 9.28 & 28.2 & 27.5 & 27.8 & 30.2 & 29.3 \\
\hline $50-54$ & 25.8 & 24.9 & 24.8 & 24.7 & 24.7 & 25.4 & 23.5 & 23.5 & 23.7 & 25.8 & 24.81 \\
\hline 55-59 & 21.3 & 21.8 & 20.9 & 20.9 & 20.7 & 21 & 19.2 & 19.2 & 19.7 & 21.5 & 20.77 \\
\hline $60-64$ & 16.9 & 17.7 & 4.16 & 2.18 & 17 & 16.8 & 15.1 & 16.2 & 16.5 & 17.2 & 16.68 \\
\hline $65-66$ & 12.6 & 13.7 & 12.1 & 14.6 & 13.3 & 12.6 & 12.1 & 13.5 & 13.4 & 14.2 & 13.13 \\
\hline $70-74$ & 9.3 & 11.2 & 7.9 & 11.2 & 9.5 & 8 & 8.6 & 8.8 & 8.6 & 9.7 & 9.33 \\
\hline $75-79$ & 6.4 & 7.5 & 5 & 8.8 & 6.1 & 5.5 & 5.3 & 6.8 & 6.9 & 6 & 6.34 \\
\hline $80-84$ & 2.9 & 4.5 & 2.7 & 4.2 & 2.8 & 3.1 & 2 & 2 & 2.1 & 2.7 & 3.34 \\
\hline+85 & 0.96 & 2.2 & 1.1 & 2.2 & 1.1 & 2.3 & 1 & 1.1 & 1.1 & 1 & 1.44 \\
\hline
\end{tabular}


Table 2. Life expectancy at birth (y) for females in 10 towns of Kurdistan Province, 2013

\begin{tabular}{|c|c|c|c|c|c|c|c|c|c|c|c|}
\hline $\begin{array}{l}\text { Age } \\
\text { Groups }\end{array}$ & Sanandaj & Saqqez & Marivan & Baneh & Qorveh & Kamyaran & Bijar & Dehgolan & Divandareh & Sarvabad & $\begin{array}{l}\text { Age } \\
\text { Median }\end{array}$ \\
\hline-1 & 72.5 & 73.5 & 70.3 & 74 & 72.7 & 72.5 & 71.2 & 69.9 & 72.6 & 72.1 & 72 \\
\hline $1-4$ & 71.8 & 72.8 & 69.8 & 73.8 & 70.8 & 71.6 & 70.2 & 70.3 & 68.7 & 71.8 & 71.3 \\
\hline $5-9$ & 68.9 & 71.1 & 67.1 & 72.9 & 68.6 & 69.4 & 68.9 & 68.2 & 67 & 68.7 & 70.9 \\
\hline $10-14$ & 63.9 & 66.2 & 62.3 & 68 & 63.6 & 64.7 & 64.1 & 63.1 & 62.1 & 63.9 & 64.3 \\
\hline $15-19$ & 59 & 61.3 & 57.2 & 63.1 & 58.8 & 57.7 & 56.1 & 58.4 & 57.1 & 59.1 & 65.2 \\
\hline $20-24$ & 54.2 & 56.4 & 52.6 & 58.2 & 54 & 55 & 54.3 & 53.8 & 52.7 & 54.2 & 54.6 \\
\hline $25-29$ & 49.3 & 51.6 & 47.8 & 53.3 & 49.2 & 50.3 & 49.5 & 49.4 & 47.9 & 49.6 & 49.8 \\
\hline $30-34$ & 44.3 & 46.8 & 42.8 & 48.2 & 44.4 & 45.4 & 44.6 & 44.4 & 43 & 44.7 & 44.9 \\
\hline $35-39$ & 39.6 & 41.8 & 37.9 & 43.7 & 39.5 & 40.7 & 39.7 & 39.5 & 38.1 & 39.9 & 40.1 \\
\hline $40-44$ & 34.6 & 37 & 33.1 & 38.8 & 34.7 & 36 & 34.7 & 34.7 & 33.5 & 35 & 35.3 \\
\hline $45-49$ & 30 & 32.1 & 28.3 & 34.1 & 29.8 & 31.1 & 30 & 29.8 & 28.6 & 30.3 & 30.5 \\
\hline $50-54$ & 25.3 & 27.5 & 23.8 & 29.5 & 24.9 & 26.2 & 25.5 & 24.1 & 24.1 & 25.5 & 25.8 \\
\hline $55-59$ & 20.5 & 23.7 & 20 & 24.6 & 20.6 & 21.7 & 20.8 & 19.8 & 19.8 & 21 & 24.4 \\
\hline $60-64$ & 16.1 & 19.2 & 15.7 & 20.6 & 16.4 & 17.4 & 16.2 & 16.4 & 15.4 & 16.9 & 17.4 \\
\hline $65-69$ & 11.9 & 15.1 & 11.8 & 16.6 & 11.9 & 13 & 12.7 & 11.9 & 11.7 & 12.7 & 13 \\
\hline $70-74$ & 8.1 & 11 & $2 / 9$ & 12.9 & 8.1 & 9.4 & 8.8 & 12.2 & 8.1 & 9.3 & 9.4 \\
\hline $75-79$ & 6.8 & 7.3 & 6.4 & 8.2 & 5.4 & 6.5 & 5.5 & 7.2 & 5.1 & 6.3 & 6.4 \\
\hline $80-84$ & 2.7 & 4.5 & 3.6 & 4.1 & 2.6 & 3.2 & 2.7 & 3.1 & 2.6 & 3.3 & 3.3 \\
\hline+85 & 1 & 2.1 & 1.2 & 2.3 & 1 & 2.1 & 1 & 1.3 & 1 & 1.1 & 1.4 \\
\hline
\end{tabular}

province is 72 years (Table 3 ). Life expectancy in some rural areas such as Baneh is almost equal to the average life expectancy of women in the country, this rate is 74 years in Baneh and Women in rural areas of Dehgolan have the low- est life expectancy this rate is 70 years. Among men, the highest level of life expectancy is in rural areas of Saqqez this rate is 70.9 years and men in rural areas of kamyaran

Table 3. Comparison of average life expectancy at birth for men and women in rural areas of Kurdistan Province, 2013

\begin{tabular}{cccccccccccc}
\hline Sex & Sanandaj & Saqqez & Marivan & Banah & Qorvah & Kamyaran & Bijar & Divandareh & Sarvabad & $\begin{array}{c}\text { Dehgolan } \\
\text { Median }\end{array}$ \\
\hline Male & 70.6 & 68.6 & 68.9 & 68.6 & 68.5 & 69.2 & 69.9 & 70.9 & 69.6 & 68.7 & 69.4 \\
Female & 72.5 & 72.6 & 71.2 & 72.5 & 72.7 & 74 & 70.3 & 73.5 & 72.1 & 69.9 & 72.1 \\
\hline Median & 71.6 & 70.4 & 70.1 & 70.5 & 70.6 & 71.9 & 70.1 & 72.2 & 71 & 69.3 & 70.8 \\
\hline
\end{tabular}

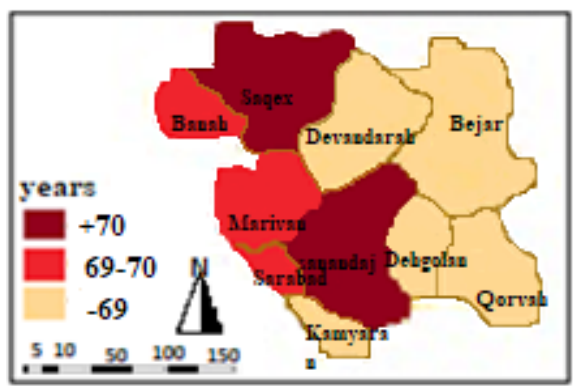

Figure 1. Life expectancy for men in rural areas of Kurdistan Province, 2013 


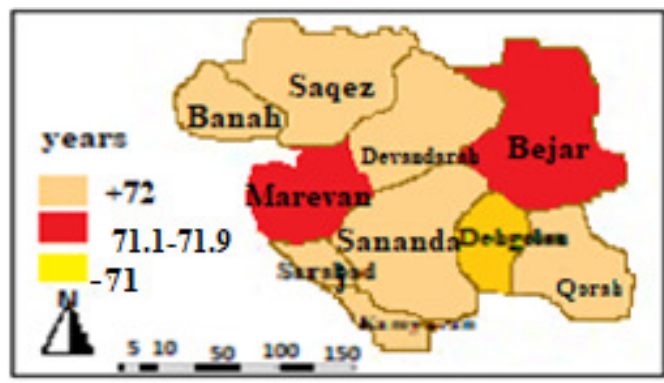

Figure 2. Life expectancy for women in rural areas of Kurdistan Province, 2013

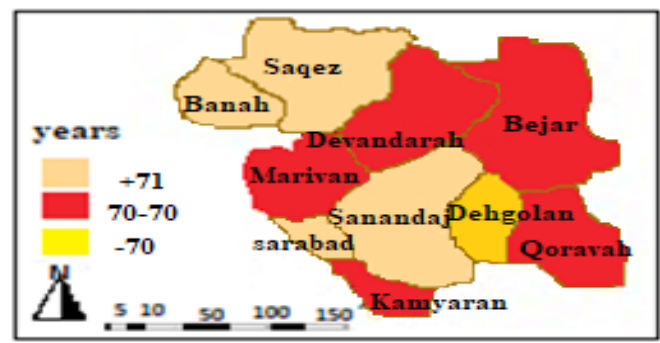

Figure 3. Average life expectancy in rural areas of Kurdistan Province, 2013

and Devandarah have the lowest life expectancy, this rate is 68.8 years (Figures 1, 2 and 3 ).

In this study, the life expectancy, as one of the indicators of health development, was investigated in rural areas of Kurdistan Province in 2013 for women and men, and the results were compared to the national average. The results showed that the life expectancy level for the whole country was 71 years for men and 74 years for women, while in rural areas of Kurdistan Province, the life expectancy was 69 years for men and 72 years for women. This indicates that the years of life expectancy for men and women in Kurdistan Province is about 2 years less than the national average. The results are consistent with the results of Taheri Bazkhaneh et al. [3], Monsef [13], Sarlak and Savari [14].

There was a big difference between the years of life expectancy among men and women in ten towns of Kurdistan Province. This indicates an unequal distribution of health facilities and services. The highest and lowest life expectancy levels for men were in Sanandaj (70.6 years) and Bijar (69.9 years), respectively. For women, the highest and lowest life expectancy levels were in Saqqez (73.5 years) and Divandereh (69.4 years), respectively.

One of the important factors of inequality in life expectancy among men and women in Kurdistan Province compared to national average is the unequal distribution of health facilities and services and the second is the lack of funds for development of health services (e.g. construction of clinics, nursing homes, and health centers) as reported in a survey conducted by the Statistics Center of Iran [15]. The rank of Kurdistan Province is low in terms of health indicators. This is consistent with the results of Shohani [16], Zarrabi and Shaykh Baygloo [17], and Bahrami and Nouri [18].

\section{Conclusion}

Establishing health is one of the fundamental principles of development. Since the human factor has a special role in the economic growth and development of countries, one of the measures to increase productivity and accelerate the economic growth is to improve the level of life expectancy. It was concluded that the life expectancy in rural areas of Kurdistan Province is unfavorable and lower than the national average. In order to improve the life expectancy in rural areas of Kurdistan Province, It is suggested that the principle of social justice should be considered both at national and regional levels during funding allocation, and rural areas with low life expectancy should be given priority during health planning.

\section{Ethical Considerations}

\section{Compliance with ethical guidelines}

There were no ethical considerations to be considered in this research. 


\section{Funding}

This research did not receive any grant from funding agencies in the public, commercial, or non-profit sectors.

\section{Authors' contributions}

Both authors equally contributed to preparing this article.

\section{Conflict of interest}

The author declare no conflict of interest.

\section{Acknowledgments}

The authors would like to thank Payam-e Noor University in Kermanshah Province for their cooperation.

\section{References}

[1] Aleemran R, Aleemran SA. [Income inequality and life expectancy in Iran (Persian)]. Payesh. 2014; 13(5):533-40. http:/ / payeshjournal.ir/article-1-274-fa.html

[2] Lotfalipour M, Falahi M, Borji M. [The effects of health indices on economic growth in Iran (Persian)]. J Health Adm 2012; 14(46):57-70. http://jha.iums.ac.ir/browse.php?a id $=1024 \&$ sid $=1 \&$ slc_lang $=$ fa

[3] Taheri Bazkhaneh S, Karimzadeh M, Tahsili H. [Study of socioeconomic factors affecting on life hope in Iran (Persian)]. Econ J. 2015; 15(1, 2):77-94. https:/ / ejip.ir/article-1-735-fa.html

[4] Pourmalek F. [Development goals in the third millennium "Pact of Nations to eradicate poverty" (Persian)]. Soc Welf Q. 2003. 2(8):25-45. https://www.sid.ir/fa/Journal/ViewPaper. aspx?id=5197

[5] World Health Organization. World health statistics 2016: monitoring health for the SDGs, sustainable development goals [Internet]. 2016 [Updated 2016]. Available from: https:/ / apps.who int/iris/handle/10665/206498

[6] Sarafrazian S, Motamed N, Tahmasebi R, Amiri M. [Estimation of life expectancy at birth in districts of Bushehr Province in 2006 and 2011 (Persian)]. Iran South Med J. 2015; 18(4):751-60. http://ismj.bpums.ac.ir/browse.php?a_code=A-10-3-626\&slc lang $=$ fa\&sid $=1$

[7] Zanganeh M. [Evaluation and analysis of human development indices in urban areas (Persian)]. Geogr Urban Space Dev. 2016, 3(1):149-60. https://jgusd.um.ac.ir/article_25645.html?lang=en

[8] Jafari Samimi A, Montazeri Shoorekchali J, Tatar M. [Life expectancy and economic growth in Iran: Smooth Transition Regression (STR) approach (Persian)]. Q J Econ Growth Dev Res. 2014; 4(13):117-28. http://egdr.journals.pnu.ac.ir/article_621.html?lang=en

[9] Khaksar S, Yazdani Charati J. Life Expectancy Trends in Mazandaran Province, 2005-2011. J Mazandaran Univ Med
Sci. 2015; 25(128):91-96 http://jmums.mazums.ac.ir/browse php?a_id $=6124 \&$ sid $=1 \&$ slc_lang $=f a$

[10] Fatholahi J, Kafili V, Tagizadegan A. [Development gap in Provinces of Iran (Persian)]. J Dev Econ Plann. 2018; 5(2):99-118 http://jdep.iaukhsh.ac.ir/article_530203.html?lang=fa

[11] The Statistics Center of Iran. Census 2016 [Internet]. 2016 [Updated 2016]. Available from: https://irandataportal.syr. edu/census/census-2016

[12] Shahoei R, Nouri B, Darvishi N, Rezaie K, Zandi H, Bayazidi S, et al . Prevalence of menstrual disorders and its related factors in the students of Kurdistan University Of Medical Science in 2018. Sci J Kurdistan Univ Medical Sci. 2020 25(4):31-41. http://eprints.muk.ac.ir/4568/

[13] Monsef A, Shahmohammadi Mehrjardi A. [Economic factors and life expectancy in 136 countries during 2002 to 2010 (Persian)]. Payesh. 2017; 16(5):567-74. http:// payeshjournal. ir/article-1-79-fa.html

[14] Sarlak A, Savari A. [The impact of socio-economic factors on life expectancy in Iran (Persian)]. J Healthc Manage. 2017; 7(3):7-15. https://jhm.srbiau.ac.ir/article_10215 html?lang=fa

[15] The Center of Strategic Studies. Strategic problematics in Kurdistan Province [Internet]. 2017 [Updated 02 February 2017]. Available from: http://www.css.ir/Media/PDF/1396 /07/18/636432528529484831.pdf

[16] Shohani N, Vesi Nab B, Khodayi S, Amirian S. [Assessing development status of health - Treatment indicator by using planning techniques and providing a composite model (case study: Zagros region) (Persian)]. J Stud Hum Settlements Plann. 2018; 13(1):235-50. http://jshsp.iaurasht.ac.ir/article_540514.html?lang=fa

[17] Zarrabi A, Shaykh Baygloo R. [Classification of Provinces of Iran by health indicators (Persian)]. Soc Welf Q. 2011 11(42):107-28. http:/ / refahj.uswr.ac.ir/article-1-729-fa.html

[18] Bahrami R, Noori K. Perceptual analysis - Spatial development indicators of health services in Kurdistan. J Geogr Notion. 2018; 9(17):119-37. http://geonot.znu.ac.ir/article_30076.html?lang=fa 